

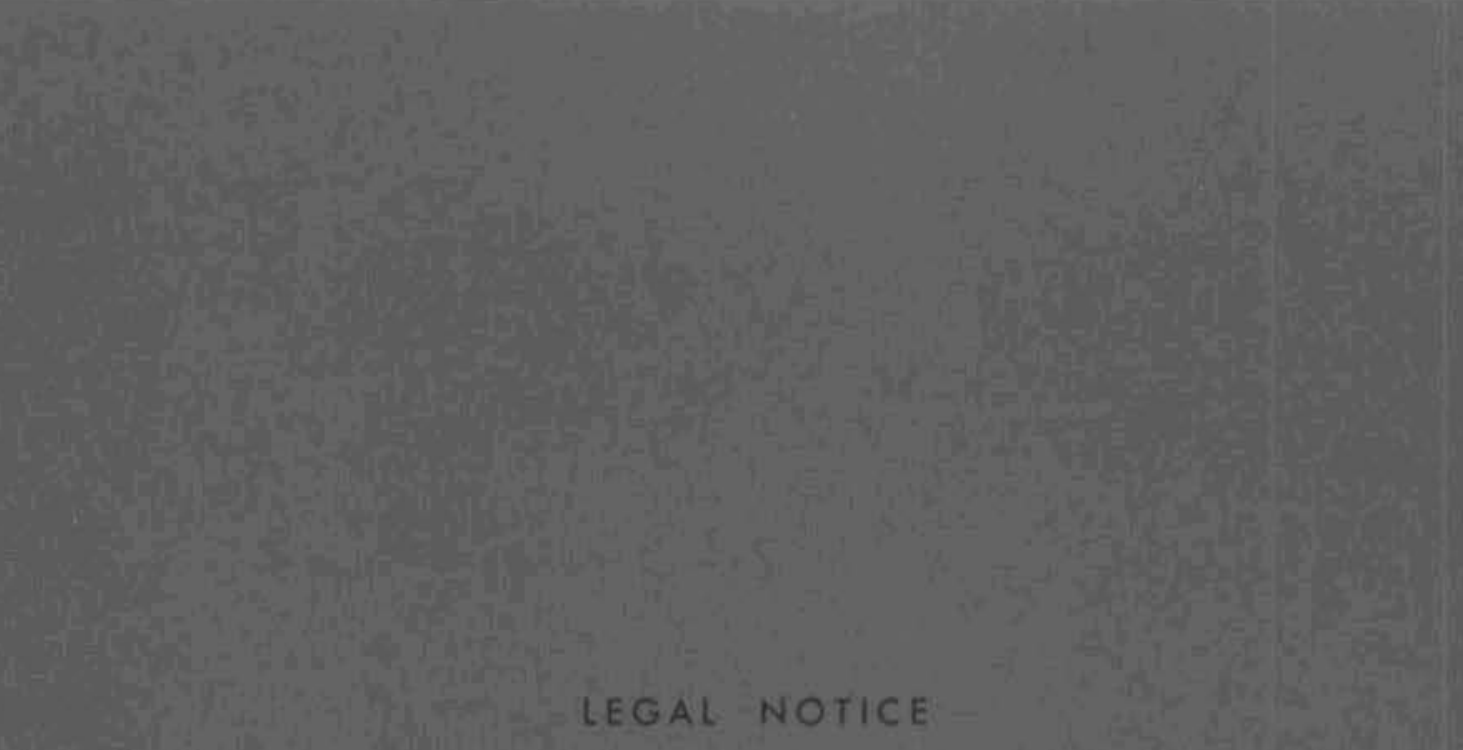

This tepon was prepored as an account of Government sponsaned work. Neither the Unlted States, nor the Commission, nor any person acting on behalf of the Commistion:

A. Makes any warranty of repretentation, expressed or implied, with respect to the accuracy, complateness, or usefulness of the information contained in this report, or that the use of any information; apparatus, method, or process disclosed in this report may not infringe privately owned rights: or

B. Assumes any liabilitios with respect to the use of, of for damoges resulting from the wie of any information, opporalus, method, or process disclased in this report.

As used in the above, "person octing on behalf of the Commissian" includes any employes or contractor of the Commision, or employee of such controctor, to the extent that-such employee or contractor of the Commission, or employee of iuch contractor prepares, disseminates, or provides occens to, ony informotion pursuont to his employment or contract with the Commission, of his employment with such contractor.

\section{PACIFIC NORTHWEST LABORATORY \\ NICHLAND. WASHINGTON \\ operated by \\ BATTELLE MEMORIAL INSTITUTE}

for the

UNITED STATES ATOMIC ENERGY COMMISSION UNDER CONTRACT AT(45-1)-1830 


\section{8}

BNWL- 502

UC-25, Metals, Ceramics, and Materials

\section{RADIATION STUDIES ON GRAPHITE \\ WITH CONTROLLED PROCESSING}

\section{By}

J. H. Cox, Jr.

Ceramics and Graphite Research Section

Materials Department

$$
\text { August, } 1967
$$

DIIST UNRESTRICTED OCT $\$ 2,67$ 
Printed in the United States of America Available from

Clearinghouse for Federal Scientific and Technical Information National Bureau of Standards, U.S. Department of Commerce Springfield, Virginia 22151

Price: Printed Copy $\$ 3.00 ;$ Microfiche $\$ 0.65$ 


\title{
RADIATION STUDIES ON GRAPHITE WITH CONTROLLED PROCESSING
}

\begin{abstract}
This investigation explored the effect of graphitization temperature, crystallite orientation, impregnation, and density on the dimensional stability of graphite under neutron irradiation. The irradiations in a Hanford test facility accumulated exposures up to $2 \times 10^{21} \mathrm{nvt}(\mathrm{E}>0.18 \mathrm{MeV})$ at temperatures in the range 550 to $700{ }^{\circ} \mathrm{C}$.

The investigation of the effect of graphitization temperature involved five series of samples, with final processing temperatures of 700 to $3000{ }^{\circ} \mathrm{C}$. Increased processing temperature resulted in an appreciably lower radiation induced contraction rate; however, the most pronounced effect was found at temperatures below $2500{ }^{\circ} \mathrm{C}$.

In graphites identical except for crystallite orientation a linear relationship was found between coefficient of thermal expansion values and contraction rates. A higher coefficient of thermal expansion resulted in a lower contraction rate.

In graphites identical except in impregnant level, increasing the impregnant level above a threshold, $16 \%$ for the series studied, resulted in the contraction rate increasing with impregnant leve1.

Increasing the density of graphite did not affect the radiation induced dimensional changes.
\end{abstract}




\section{TABLE OF CONTENTS}

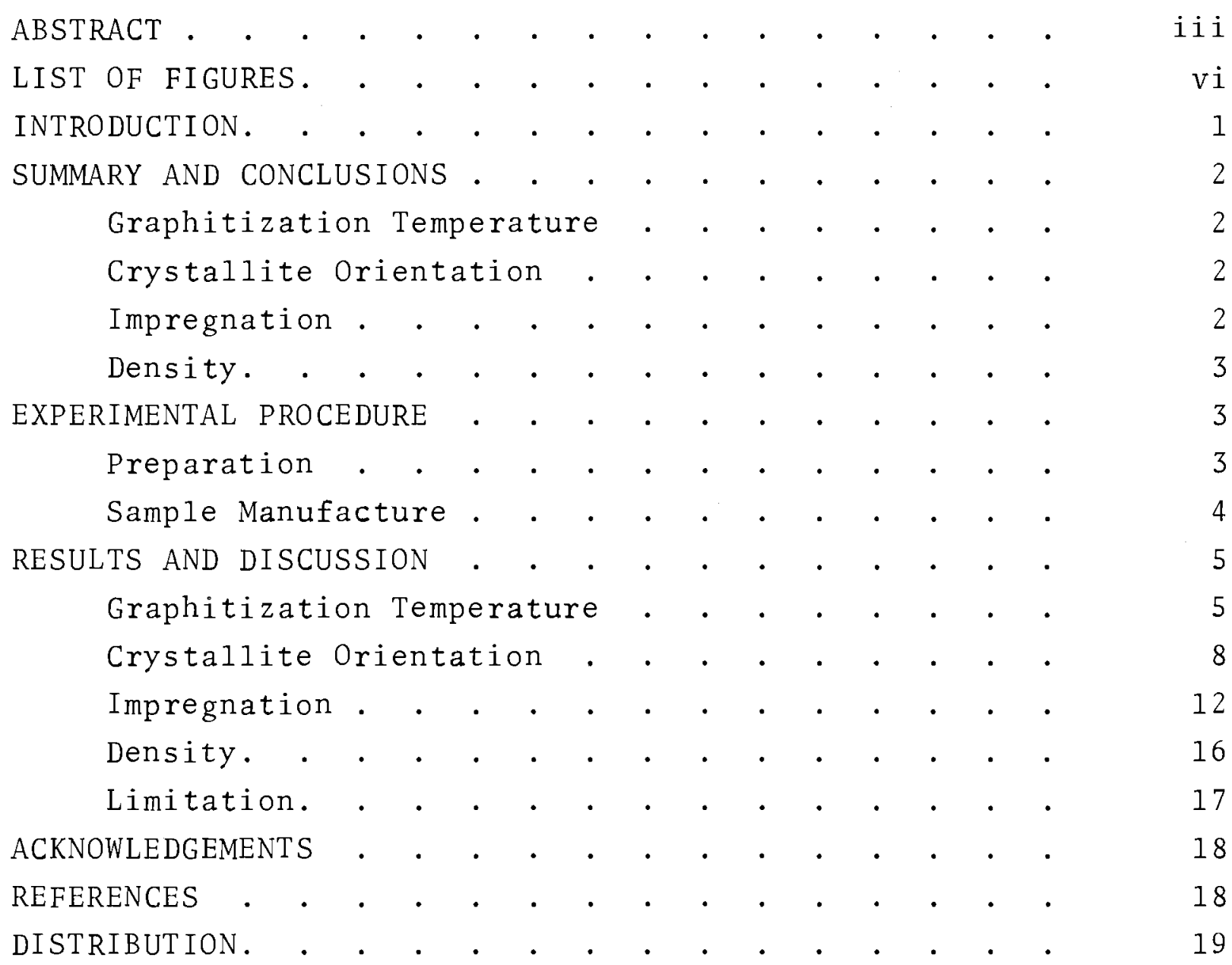




\section{LIST OF FIGURES}

1 Texas Coke Graphitization Series, Radiation Induced Length Changes (Transverse Orientation)

2 Needle Coke Graphitization Series, Radiation Induced Length Changes

3 Pregraphitized Needle Coke Series, Radiation Induced Length Changes (Transverse Orientation)

Pregraphitized Needle Coke Series, Radiation Induced Length Changes (Parallel Orientation)

Carbon Black Graphitization Series, Radiation Induced Length Changes

6 Glassy Carbon Graphitization Series, Radiation Induced Length Changes

7 Controlled Orientation Series, Radiation Induced Contraction Rate Versus Coefficient of Thermal Expansion

Impregnant Level Series, Radiation Induced Contraction Rate Versus Percent Impregnant (Transverse Orientation

9 Impregnant Level Series, Radiation Induced Contraction Rate Versus Percent Impregnant (Parallel Orientation) 


\section{RADIATION STUDIES ON GRAPHITE \\ WITH CONTROLLED PROCESSING}

J. H. Cox, Jr.

\section{INT RODUCT I ON}

A number of process variables exist which are controllable during graphite manufacture. This investigation explores the effects of several of these variables upon the dimensional stability of graphite during neutron irradiation. Variables investigated are graphitization temperature, crystallite orientation, impregnation level, and density. We attempted to hold all variables constant except for the one being studied.

The graphitization temperatures were varied for graphitic materials made from needle coke, non-needle coke, or from a pregraphitized coke and non-graphitic material such as glassy carbon and carbon black filler material; graphitization temperatures ranged from 700 to $3500{ }^{\circ} \mathrm{C}$ in the extreme cases. The crystallite orientation was varied in a sample set by utilizing different forming techniques to yield coefficient of thermal expansion values ranging from 0.5 to $3.0 \times 10^{-6}{ }^{\circ} \mathrm{C}$. A sample set was impregnated with coal-tar pitch and with thermosetting resin to levels from 1.0 to 21.0 wto impregnant. A density series was investigated ranging from 1.3 to $1.7 \mathrm{~g} / \mathrm{cc}$.

These studies aim to provide data which help to define the damage mechanism in nuclear graphite and to lead to the manufacture of a product more stable during neutron irradiation. 


\section{SUMMARY AND CONCLUSIONS}

\section{GRAPHITIZATION TEMPERATURE}

Increasing the graphitization temperature and, therefore, the degree of graphitization, as determined by crystallite layer spacing and/or ordering, results in a lower contraction rate for all reported temperatures. The increase in temperature becomes less effective above $2500{ }^{\circ} \mathrm{C}$; however, there is an appreciable reduction in contraction rate to $3000{ }^{\circ} \mathrm{C}$. The reduced contraction with increased processing temperature is independent of coefficient of thermal expansion values. CRYSTALLITE ORIENTATION

In graphites identical except in the relative orientation of the crystallites within the graphite matrix, one may predict contraction rates under neutron irradiation for different orientations based on contraction rate data for any one orientation. Although the calculated single-crystal dimensional changes found in this study are less than those found in pyrolytic graphite, these data are quantitatively consistent with a single-phase mode1.

\section{IMPREGNATION}

The impregnant level has a definite effect on the contraction rate of graphite under neutron irradiation. At higher impregnant levels, approximately 16 percent for the graphite studied in this work, the contraction rate increases with impregnant level. A plausible explanation is that at low impregnant levels the open pore volume is preferentially filled, and there is no effect on the dimensional behavior of the bulk. However, as the open pores are filled and the binder assumes part of the supporting structure, there is an increased contraction rate since the binder is contracting at a more rapid rate than the filler. These observations support a two-phase model. 


\section{DENSITY}

In the series studied, including densities from 1.3 to 1.7 $\mathrm{g} / \mathrm{cc}$, there is no evidence that density alone has an effect on the radiation induced contraction in graphite.

\section{EXPERIMENTAL PROCEDURE}

\section{PREPARATION}

The samples were machined to 0.426-in. diameter by 4 -in. long cylinders, and the rounded ends were polished. All samples with processing temperatures above $1000{ }^{\circ} \mathrm{C}$ were annealed at $1000{ }^{\circ} \mathrm{C}$ to relieve any residual machining stresses.

Property measurements included length, coefficient of thermal expansion, and crystallite dimensions. Lengths were measured with a Bausch and Lomb DR-25 Optical Gage (Type 33-14-23). The length measurements had a standard deviation of $2 \times 10^{-5}$ in. Coefficient of thermal expansion values were determined from 25 to $425^{\circ} \mathrm{C}$ using a quartz drive and a Starrett gage (No. 656-611) allowing a standard deviation of approximately $5 \times 10^{-2} \mathrm{in} / \mathrm{in}{ }^{\circ} \mathrm{C}$. The apparent crystalite dimensions and the crystallite lattice spacings in the $\underline{c}$ and $\underline{a}$ directions were determined by $x$-ray measurements. Those measurements in the a direction were made from the reflection (110) on solid samples; measurements in the c direction were made from the reflection (002) on powdered samples. The apparent crystallite size, L, was calculated from the breadth of the X-ray diffraction line by the Scherrer equations,

$$
L=\frac{k \lambda}{\beta \cos \theta}
$$

where $k$ is the shape factor and $\beta$ is the intrinsic line breadth.

The samples were irradiated in hollow graphite bars equipped with sliding covers at the Hanford reactor irradiation facilities. The irradiation temperature varied from 550 to $700{ }^{\circ} \mathrm{C}$ and the capsule atmosphere, the same for all samples, was a mixture of helium and carbon dioxide. 
The incident neutron exposures ( $\mathrm{E}>0.18 \mathrm{MeV}$ ) are determined from the activation of nickel, iron, and cobalt monitors, and from the calculated neutron spectra for the irradiation facility. All wire counting was done with the gamma analytical system ${ }^{(1)}$ at Hanford. The experimental details for determining the neutron exposures are discussed by Morgan ${ }^{(2)}$ in the description of the computer code (FOILS) used.

SAMPLE MANUFACTURE

Five heat treatment series were available for this study: 1) The first series consists of a molded Texas coke series (3) processed at various temperatures from 1300 to $2700{ }^{\circ} \mathrm{C}$. The degree of graphitization, as determined by crystalite size and layer spacing, increased with increasing graphitization temperature. 2) The second series was extruded from needle coke and graphitized at $200{ }^{\circ} \mathrm{C}$ steps, from 2400 to $3000{ }^{\circ} \mathrm{C}$. 3) The third series (4) was extruded from needle coke and pregraphitized at $2900^{\circ} \mathrm{C}$. The final process temperature was varied from 700 to $2900^{\circ} \mathrm{C}$. 4) The fourth series was glassy carbon ${ }^{(5)}$ heat treated at 1000,2000 , and $3000^{\circ} \mathrm{C}$. 5) The fifth series was molded from a mix of $50 \%$ carbon black and $50 \%$ binder coke. (6) The formed pieces were processed at 1400,3000 , and $3500{ }^{\circ} \mathrm{C}$.

The series of controlled-orientation samples (6) was made by either molding, extruding, or a combination of both. The green mix, consisting of Continental coke flour and 30 medium pitch as binder, was extruded as 5-1/8 in. diameter rounds. The green stock was reformed by molding with the force applied parallel to the extrusion axis. The molding pressure was adjusted to yield plugs with a reversal of the orientation induced by the initial extrusion. A final set was molded as 6-1/8 in. diameter rounds directly from the green mix. The stock was then graphitized at $3000{ }^{\circ} \mathrm{C}$. 
The impregnation-level series of samples (6) was made from base stock of a mix of Continental coke filler and 30 medium coal-tar pitch binder extruded with a $41 / 2$ by $41 / 2$ in. cross section. The binder-carbon content varied from 10.5 to $12 \%$. The formed bars were impregnated with coal-tar pitch and with thermosetting resin to various levels from 1 to 21 wt . After impregnation, the samples were graphitized at $3000^{\circ} \mathrm{C}$. The processing of this series increased the amount of less-graphitic carbon in the selected filler system so that irradiation effects originating in the non-graphitic portions could be more easily perceived. The most convenient method by which carbon may be added to a particular filler system is by impregnating previously formed graphite with either pitch or resins and then coking the impregnant. This allows one to hold other properties more constant than by varying the initial binder level.

The density series included graphites molded and extruded from needle coke. Densities ranged from 1.3 to $1.7 \mathrm{~g} / \mathrm{cc}$.

\section{RESULTS AND DISCUSSION}

GRAPHITIZATION TEMPERATURE

The initial property measurements for all graphitization series are given in Table I. As shown for the Texas coke series, there is no relationship between density or coefficient of thermal expansion and the graphitization temperature. However, the degree of graphitization, as indicated by the crystallite size and layer spacing, increases with increasing graphitization temperature. The irradiation results are given in Figure 1. Each data point shown represents an average of two samples. It is clearly shown that the dimensional stability is increased for the more graphitic material, i.e., higher graphitization temperature.

Although the increased degree of graphitization with temperature for the needle coke series is less apparent than for 
TABLE I. Graphitization Series: Initial Property Measurements

\begin{tabular}{|c|c|c|c|c|c|c|c|c|c|}
\hline \multirow{2}{*}{\multicolumn{2}{|c|}{$\begin{array}{l}\text { Graphitization } \\
\text { Temperature }{ }^{\circ} \mathrm{C}\end{array}$}} & \multirow{2}{*}{$\begin{array}{l}\text { Density } \\
\text { g/cc }\end{array}$} & \multicolumn{3}{|c|}{$\begin{array}{c}\text { Coefficient of } \\
\text { Thermal Expansion } \\
\left(25-4000^{\circ} \mathrm{C}\right) \\
\times 106 /{ }^{\circ} \mathrm{C} \\
\end{array}$} & \multicolumn{2}{|c|}{ Crystallite } & \multicolumn{2}{|c|}{ Dimensions, $\AA$} \\
\hline & & & & 1 & 11 & $\mathrm{~L}_{\mathrm{C}}$ & $\underline{c_{0}}$ & $\underline{\mathrm{L}} \mathrm{a}$ & $\underline{\mathrm{a}}$ \\
\hline \multicolumn{10}{|c|}{ Texas Coke-Coal-tar Pitch, Molded } \\
\hline & 370 & --- & & $\cdots$ & $-\cdots$ & $-\cdot$ & $\cdots$ & -- & $-\ldots$ \\
\hline & 800 & 1.51 & & 3.95 & 3.12 & 100 & 6.87 & 120 & $\cdots-$ \\
\hline & 100 & 1.50 & & 3.51 & 3.01 & 175 & 6.82 & 162 & $\cdots$ \\
\hline & 300 & 1.50 & & 3.61 & 2.70 & 215 & 6.79 & 320 & $-\cdots$ \\
\hline & 570 & 1.50 & & 4.29 & 2.85 & 300 & 6.76 & 350 & $\cdots$ \\
\hline & 700 & 1.53 & & 3.56 & 2.75 & 290 & 6.76 & 440 & -- \\
\hline
\end{tabular}

Needle Coke-Coal-tar Pitch, Molded

$\begin{array}{llllllll}2400 & 1.81 & 3.01 & 1.36 & 227 & 6.749 & 427 & 2.4619 \\ 2600 & 1.82 & 2.84 & 1.12 & 222 & 6.742 & 442 & 2.4622 \\ 2800 & 1.83 & 2.52 & 1.08 & 258 & 6.742 & 577 & 2.4619 \\ 3000 & 1.83 & 2.50 & 0.96 & 230 & 6.739 & 463 & 2.4614\end{array}$

Pregraphitized Needle Coke $\left(2900^{\circ} \mathrm{C}\right)-$ Coal-tar Pitch, Molded

$\begin{array}{rrrrrrrr}700 & 1.46 & 4.77 & 1.35 & 490 & 6.729 & 500 & 2.4557 \\ 900 & 1.51 & 4.11 & 1.68 & 520 & 6.732 & 780 & 2.4602 \\ 1400 & 1.48 & 3.41 & 1.15 & 485 & 6.729 & 1305 & 2.4595 \\ 2000 & 1.48 & 3.32 & 1.24 & 368 & 6.729 & 420 & 2.4585 \\ 2350 & 1.46 & 3.75 & 1.16 & 470 & 6.734 & 712 & 2.4580 \\ 2750 & 1.47 & 3.23 & 1.01 & 490 & 6.728 & 1485 & 2.4643 \\ 2900 & 1.50 & 3.17 & 1.04 & 600 & 6.726 & 705 & 2.4604\end{array}$

Carbon Black $(50 \%)$-Coal-tar Pitch, Molded

$\begin{array}{rrrrrrrr}1400 & 1.55 & 4.18 & 4.04 & 87 & 6.800 & \ldots & \ldots \ldots \\ 3000 & 1.60 & 4.38 & 4.24 & 152 & 6.803 & 226 & 2.459 \\ 3500 & 1.65 & -\ldots & 4.16 & 163 & 6.790 & 211 & 2.461\end{array}$

the Texas coke series, the crystallite dimensions provide some indication of greater graphitization. The irradiation data given in Figure 2 are consistent with those found in Texas coke series. Although the samples have received only one low exposure, the increased stability with increased graphitization temperature is quite apparent. 


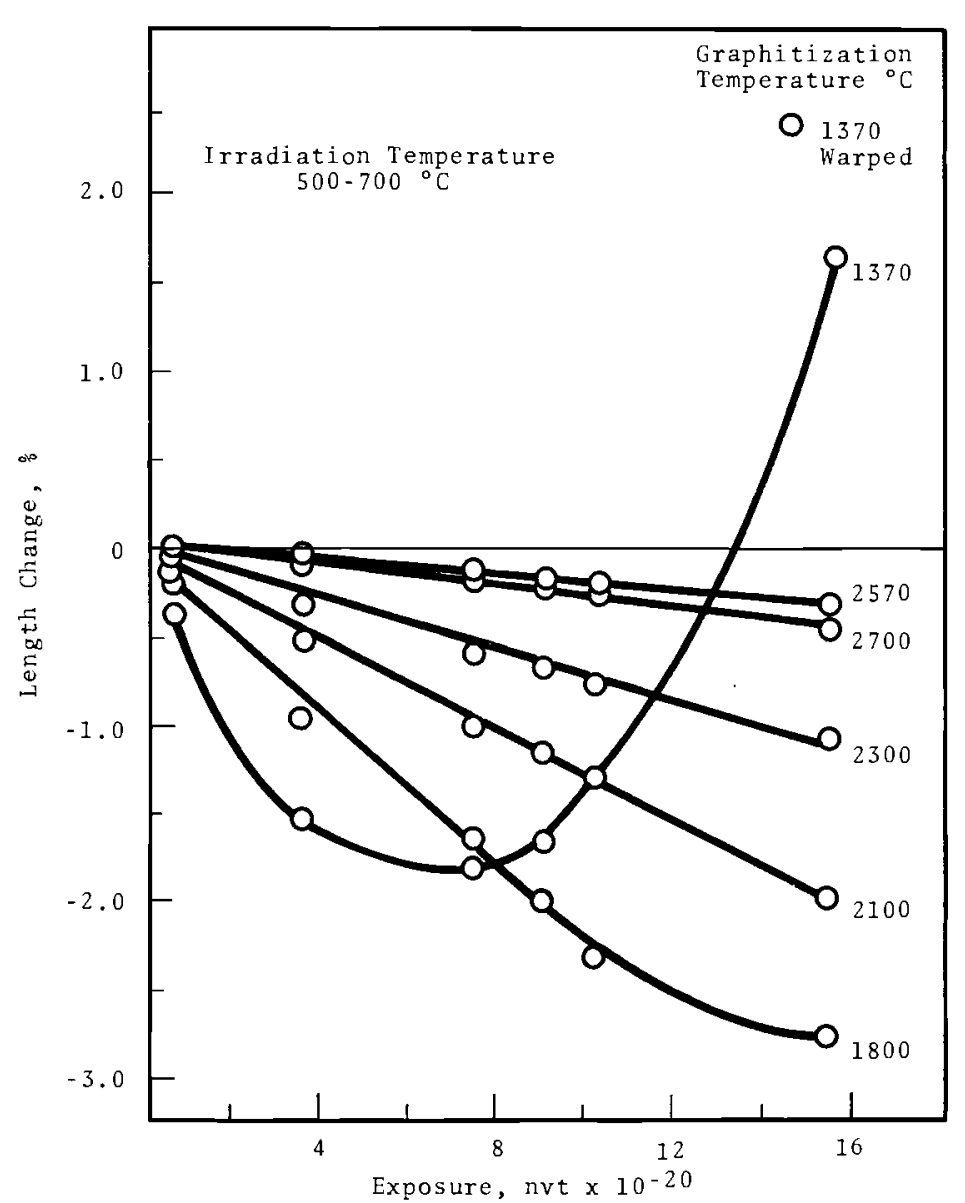

FIGURE 1. Texas coke Graphitization Series, Radiation Induced Length Changes (Transverse Orientation)

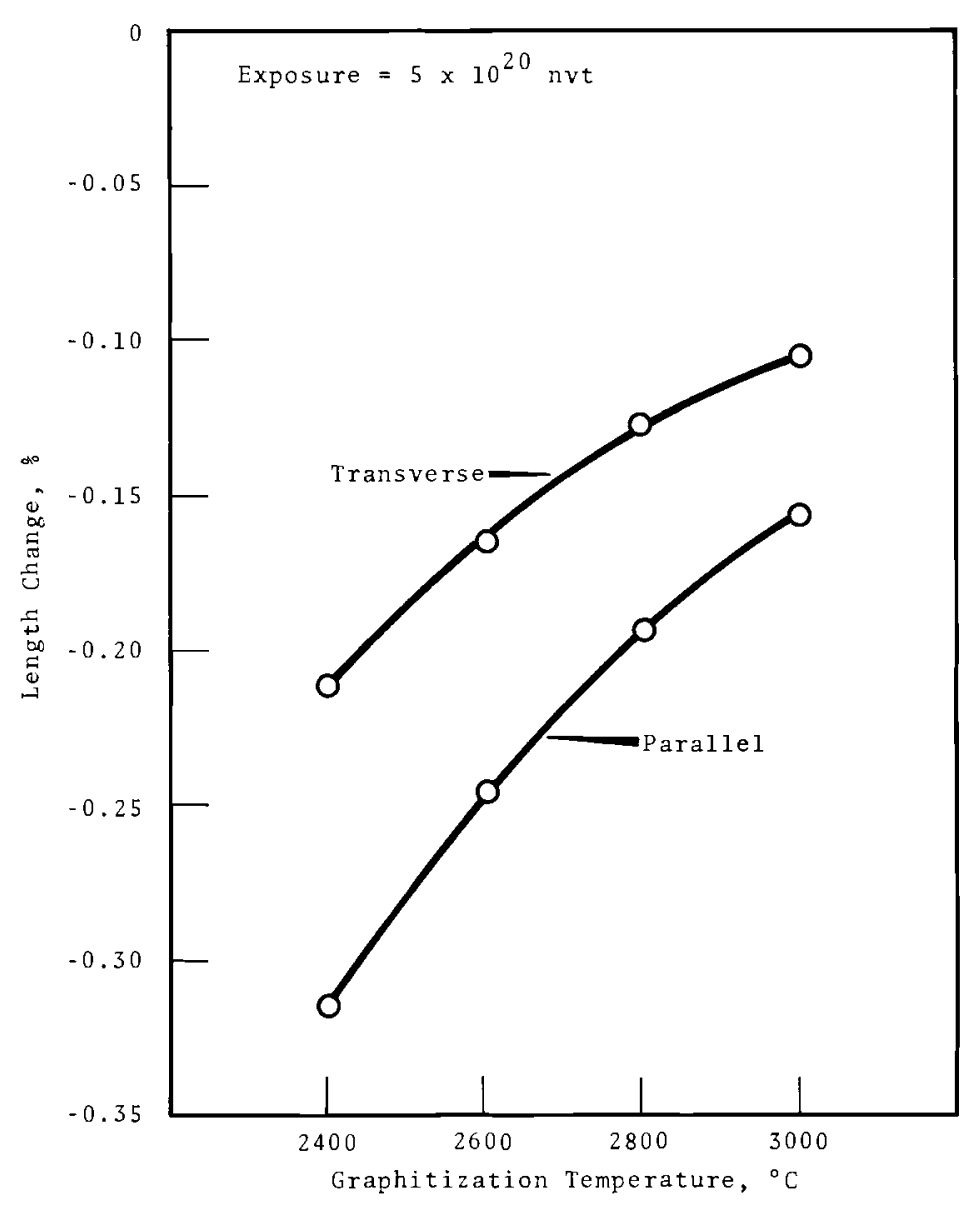

$\checkmark$

FIGURE 2. Needle Coke Graphitization Series, Radiation Induced Length Changes 
For the pregraphitized needle coke series the only apparent change with increased graphitization temperature is a reduction in the coefficient of thermal expansion; this is consistent with the needle coke graphitization series. The irradiation results are given in Figures 3 and 4. Although increasing processing temperature increases stability over the whole range, the effect is Iess pronounced above $2000^{\circ} \mathrm{C}$.

The irradiation data for the carbon black graphitization series are presented in Figure 5. The 1 ines on Figure 5 are a least square fit to the data; each line represents from 5 to 15 data points. As shown, the $1400^{\circ} \mathrm{C}$ material contracts rapidly compared to the 3000 and $3500{ }^{\circ} \mathrm{C}$ materials. The $3000{ }^{\circ} \mathrm{C}$ material is slightly more stable than that graphitized at $3500^{\circ} \mathrm{C}$. This difference may be due to the difference between cooling rates in the resistance furnace used for the $3000{ }^{\circ} \mathrm{C}$ treatment and the induction furnace for the $3500^{\circ} \mathrm{C}$ treatment.

The glassy carbon material has a density of about $1.5 \mathrm{~g} / \mathrm{cc}$ and a coefficient of thermal expansion of 2.0 to $2.2 \times 10^{-6} 1 /{ }^{\circ} \mathrm{C}$. The irradiation data are presented in Figure 6. Again the increased processing temperature has improved the stability. Thus even for a turbostratic non-graphitizing material a higher processing temperature improves dimensional stability.

\section{CRYSTALLITE ORIENTATION}

The initial coefficient of thermal expansion and the contraction rates due to neutron exposures are listed in $\mathrm{Tab}$ le II for the controlled orientation series. The contraction rate is plotted against the coefficient of thermal expansion in Figure 7 for a first test of the data; as shown, the relationship is linear within one standard deviation.

An alternative analysis of the data consists of solving the Simmons. (7) equations for single-crystal dimensional changes, knowing the crystal coefficient of thermal expansion, the 


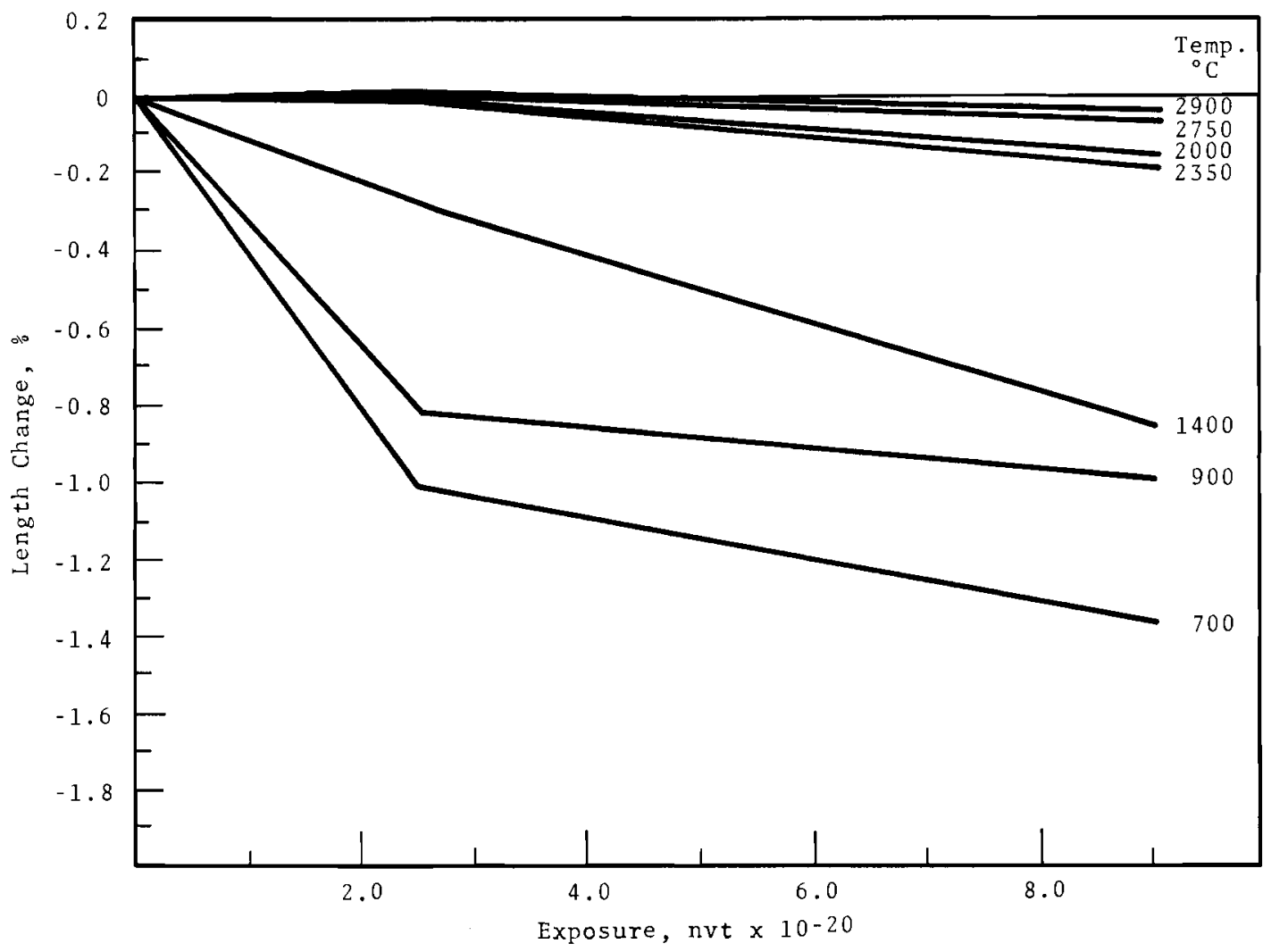

FIGURE 3. Pregraphitized Needle Coke Series, Radiation Induced Length Changes (Transverse Orientation)

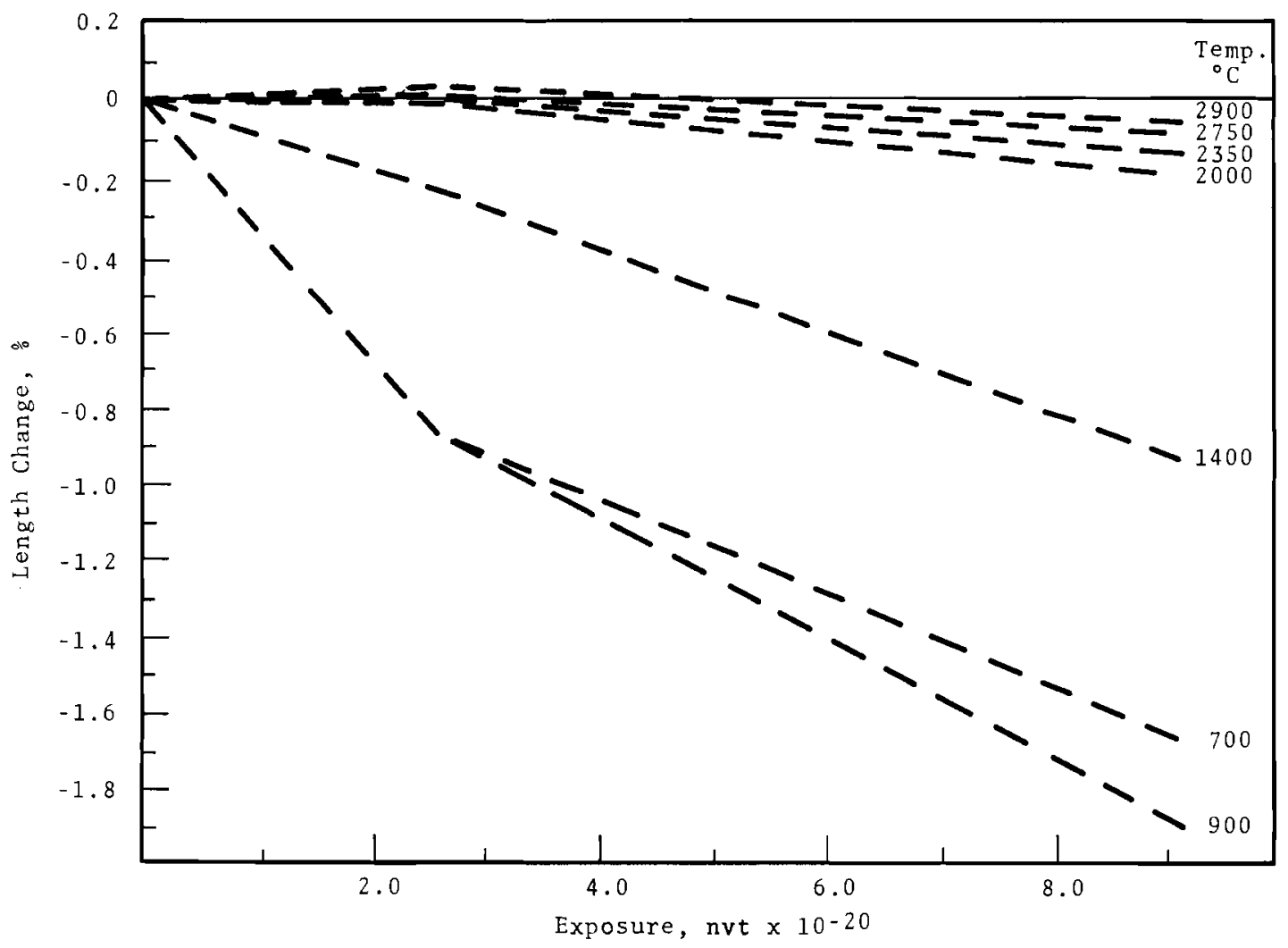

FIGURE 4. Pregraphitized Needle Coke Series, Radiation Induced Length Changes (Parallel orientation) 


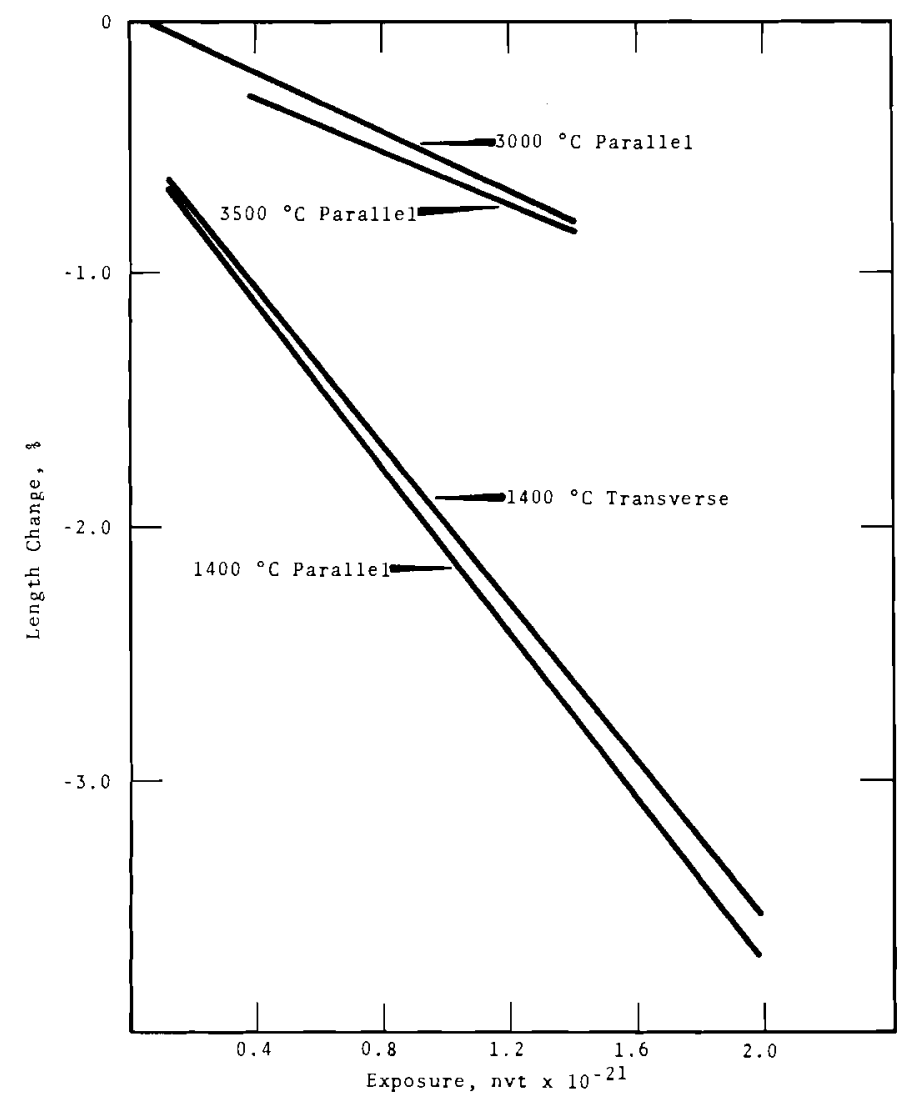

FIGURE 5. Carbon Black Graphitization Series, Radiation Induced Length Changes

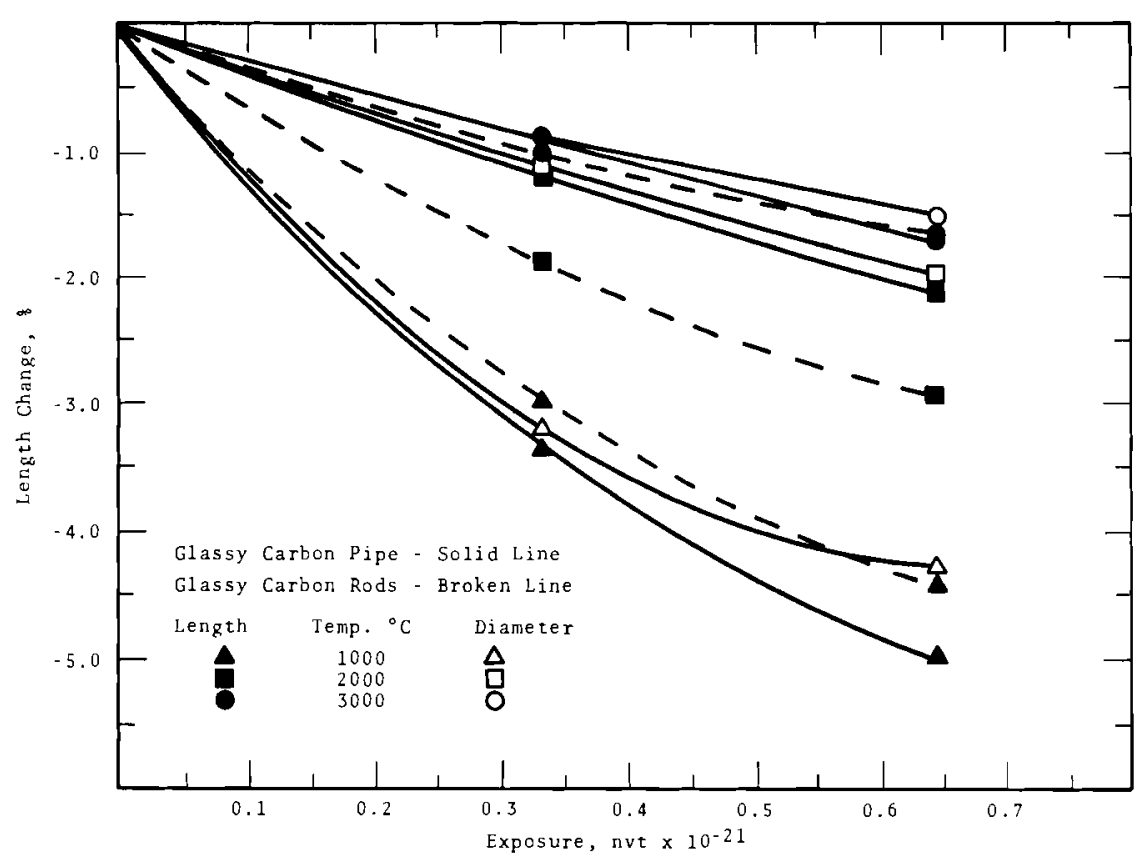

FIGURE 6. Glassy Carbon Graphitization Series, Radiation Induced Length Changes 
TABLE II. Controlled Orientation Series: Contraction Rates

(Graphite is needle coke-coal-tar pitch, molded and/or extruded.)

\begin{tabular}{|c|c|c|c|c|}
\hline $\begin{array}{l}\text { Sample Set } \\
\mathrm{T} / \mathrm{L} \text { Ratio }\end{array}$ & Orientation & $\begin{array}{c}\text { Initial } \\
\text { CTE } \times 10^{6} \\
\left(25-100{ }^{\circ} \mathrm{C}\right) \\
\end{array}$ & $\begin{array}{c}\text { Contraction Rate } \\
10 \\
102 \mathrm{nvt}(\mathrm{E}>0.18 \mathrm{MeV}) \\
\end{array}$ & $\begin{array}{l}\text { Standard } \\
\text { Deviation }\end{array}$ \\
\hline 6.18 & Transverse & 3.03 & 0.0832 & \pm 0.0185 \\
\hline 2.39 & Transverse & 2.37 & 0.0896 & \pm 0.0168 \\
\hline 0.78 & Parallel & 2.26 & 0.1020 & \pm 0.0156 \\
\hline 0.78 & Transverse & 1.76 & 0.1125 & \pm 0.0154 \\
\hline 2.39 & Paralle1 & 0.99 & 0.1156 & \pm 0.0161 \\
\hline 6.18 & Para 11 e 1 & 0.49 & 0.1328 & \pm 0.0164 \\
\hline
\end{tabular}

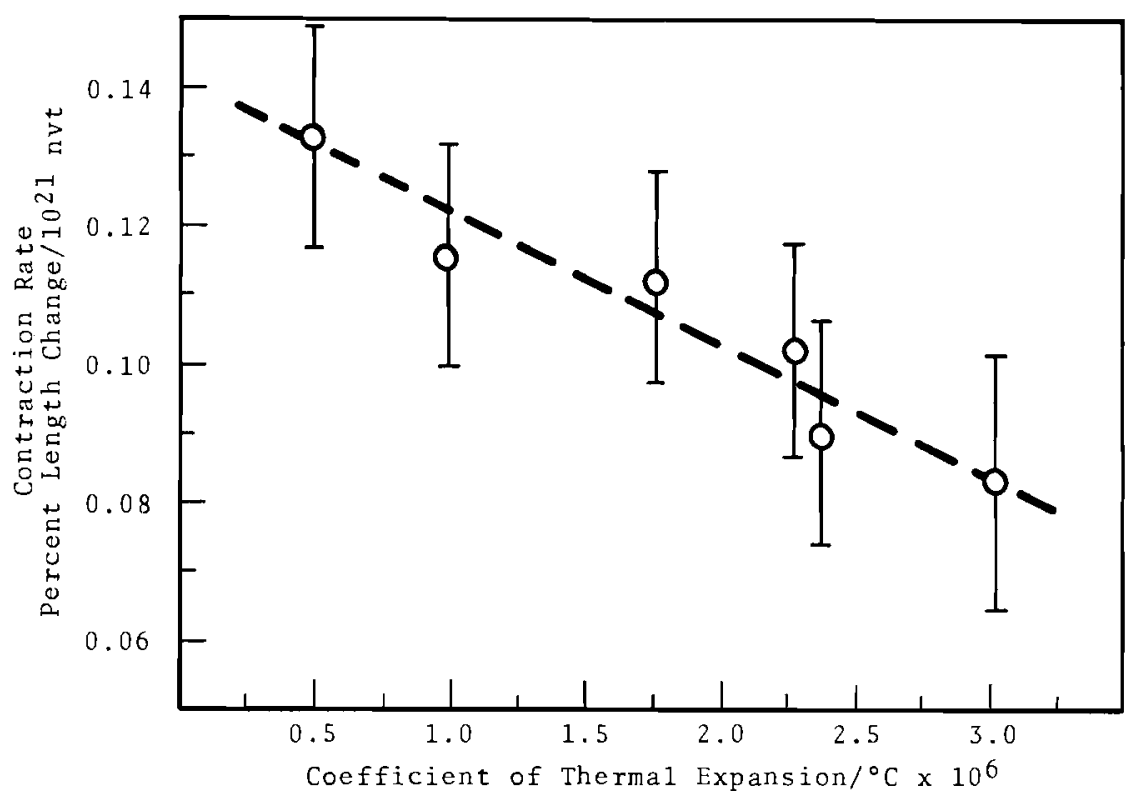

FIGURE 7. Controlled Orientation Series, Radiation Induced Contraction Rate Versus Coefficient of Thermal Expansion

aggregate coefficient of thermal expansion, and the rate of dimensional change with exposure. Thus, using the coefficients and contraction rates given in Table II, and the single-crystal coefficients given by Riley, (8) 


$$
\begin{aligned}
& \alpha_{\mathrm{C}}=26.75 \times 10^{-6} /{ }^{\circ} \mathrm{C}\left(25-100^{\circ} \mathrm{C}\right) \\
& \alpha_{a}=-1.15 \times 10^{-6} /{ }^{\circ} \mathrm{C}\left(25-100^{\circ} \mathrm{C}\right)
\end{aligned}
$$

and the Simmons' equations,

$$
\begin{gathered}
\alpha_{x}=A_{x} \alpha_{c}+\left(1-A_{x}\right) \alpha_{a} \\
\frac{1}{\ell_{x}} \frac{d \ell_{x}}{d y}=A_{x} \frac{1}{X_{c}} \frac{d x}{d \gamma}+\left(1-A_{x}\right) \frac{1}{x_{a}} \frac{d x}{d y}
\end{gathered}
$$

the accommodation factor $A_{x}$ may be found for each aggregate coefficient. Knowing the accommodation factor and the bulk growth rate, one may find the single-crystal growth rates. The growth rates were determined as $-0.167 \pm 0.007 \frac{0 \Delta L}{\mathrm{~L}} / 10^{21} \mathrm{nvt}$ for the a-axis and $+0.390 \pm 0.014 \frac{\frac{\sigma}{L} L}{L} / 10^{21} \mathrm{nvt}$ for the $\mathrm{c}$-axis.

The calculated single-crystal dimensional changes, based on the present work, are much lower than those based on pyrolytic data. $(9,10)$ However, one might expect different apparent singlecrystal changes over a range of processing temperatures or varying degrees of graphitization of the material. That is, as the material becomes more graphitic, one would expect a lower apparent crystal contraction rate as ordering in the bulk graphite improves dimensional stability. This effect of ordering can be seen in the graphitization series currently being studied.

Based on these data, the Simmons' equations provide a good relationship between the coefficient of thermal expansion and radiation induced contraction rates for materials identical except for the crystallite orientation.

IMPREGNAT I ON

The impregnation-level series may be approached in either of two ways: One may consider the dimensional stability relative to either the impregnant level or the impregnant plus binder level. The binder level for all samples, as listed in Table III, 
TABLE III. Impregnation Leve1 Series

(Graphite is needle coke-coal-tar pitch, extruded)

Impregnant Levels

\section{Binder and Impregnant (percent)}

\begin{tabular}{|c|c|c|c|c|c|c|}
\hline & & ider an & mpregnant & $n t$ & & \\
\hline & 11-Tar Pitch & & Resin & & & \\
\hline Binder & Impregnant & Tota 1 & Impregnant & Impregnant & $\begin{array}{l}\text { Binder and } \\
\text { Impregnant } \\
\end{array}$ & $\begin{array}{r}\text { Density } \\
(\mathrm{g} / \mathrm{cc}) \\
\end{array}$ \\
\hline 10.5 & 1.0 & 11.5 & --- & 1.0 & 11.5 & 1.55 \\
\hline 11.2 & 6.8 & 18.0 & --- & 6.8 & 18.0 & 1.54 \\
\hline 12.0 & 6.5 & 18.5 & --- & 6.5 & 18.5 & 1.59 \\
\hline 10.5 & $3.5(2)^{1}$ & 14.0 & --- & 3.5 & 14.0 & 1.64 \\
\hline 11.2 & $10.3(2)$ & 21.3 & --- & 10.3 & 21.3 & 1.63 \\
\hline 12.0 & 10.2 (2) & 22.2 & --- & 10.2 & 22.2 & 1.66 \\
\hline 10.5 & 1.0 & 11.5 & 6.0 & 7.0 & 17.0 & 1.69 \\
\hline 12.0 & 6.5 & 18.5 & 7.5 & 14.0 & 26.0 & 1.73 \\
\hline 10.5 & 1.0 & 11.5 & $8.8 \quad(2)$ & 9.8 & 19.8 & 1.74 \\
\hline 11.2 & 6.8 & 18.0 & $9.6 \quad(2)$ & 16.4 & 27.6 & 1.74 \\
\hline 12.0 & 6.5 & 18.5 & 10.0 & 16.5 & 28.5 & 1.78 \\
\hline 12.0 & 6.5 & 18.5 & 11.8 & 18.3 & 30.3 & 1.78 \\
\hline 12.0 & 6.5 & 18.5 & 9.5 & 16.0 & 28.0 & 1.79 \\
\hline 12.0 & 6.5 & 18.5 & $14.5 \quad(2)$ & 21.0 & 33.0 & 1.80 \\
\hline 12.0 & 6.5 & 18.5 & $11.0 \quad(2)$ & 17.0 & 29.0 & 1.81 \\
\hline
\end{tabular}

17.0

29.0 
is about $12 \%$. Thus, for this sample series, including both binder and impregnant, the nature of the curve is not changed--only the origin is shifted. The data from Tables III and IV, for the contraction rate relative to the impregnant level, are presented in Figures 8 and 9 for the transverse and parallel samples respectively. A definite effect of impregnant is shown at the higher impregnant levels, above 16\% approximately.

TABLE IV. Impregnation Level Series: Contraction Rates

\begin{tabular}{|c|c|c|c|c|}
\hline Sample Set & Orientation & $\begin{array}{r}\text { Initial } \\
\text { CTE } \times 10^{6} \\
\left(25-100{ }^{\circ} \mathrm{C}\right) \\
\end{array}$ & $\begin{array}{c}\text { Contraction Rate } \\
{ }^{2}{ }^{2} \text { Length Change/ } \\
\underline{n v t}^{\circ}(\mathrm{E}>0.18 \mathrm{MeV})\end{array}$ & $\begin{array}{l}\text { Standard } \\
\text { Deviation }\end{array}$ \\
\hline \multirow[t]{2}{*}{60} & Transverse & 2.05 & 0.091 & \pm 0.014 \\
\hline & Parallel & 0.54 & 0.124 & \pm 0.013 \\
\hline \multirow[t]{2}{*}{30} & Transverse & 2.25 & 0.086 & \pm 0.013 \\
\hline & Paralle 1 & 0.65 & 0.128 & \pm 0.015 \\
\hline \multirow[t]{2}{*}{15} & Transverse & 2.54 & 0.091 & \pm 0.014 \\
\hline & Parallel & 0.44 & 0.124 & \pm 0.013 \\
\hline $\mathrm{C}-1$ to 10 & Parallel & $\ldots$ & 0.116 & \pm 0.009 \\
\hline$B-1$ to 10 & Paralle 1 & $\ldots$ & 0.116 & \pm 0.005 \\
\hline A-1 to 10 & Paralle 1 & $\ldots$ & 0.101 & \pm 0.013 \\
\hline$C-11$ to 20 & Parallel & $\ldots$ & 0.114 & \pm 0.009 \\
\hline A-11 to 20 & Parallel & $\ldots$ & 0.117 & \pm 0.006 \\
\hline$C-21$ to 30 & Parallel & $\ldots$ & 0.130 & \pm 0.007 \\
\hline$B-21$ to 30 & Paralle1 & $\ldots$ & 0.142 & \pm 0.004 \\
\hline$A-21$ to 30 & Parallel & $\ldots$ & 0.142 & \pm 0.005 \\
\hline \multirow[t]{2}{*}{$I-1$} & Transverse & 2.13 & 0.164 & \pm 0.011 \\
\hline & Parallel & 0.86 & 0.156 & \pm 0.009 \\
\hline \multirow[t]{2}{*}{$I-2$} & Transverse & 2.13 & 0.136 & \pm 0.017 \\
\hline & Parallel & 0.78 & 0.133 & \pm 0.017 \\
\hline \multirow[t]{2}{*}{$I-3$} & Transverse & 2.23 & 0.183 & \pm 0.019 \\
\hline & Parallel & 0.82 & 0.194 & \pm 0.014 \\
\hline \multirow[t]{2}{*}{$I-4$} & Transverse & 2.36 & 0.133 & \pm 0.012 \\
\hline & Parallel & 0.71 & 0.132 & \pm 0.013 \\
\hline
\end{tabular}




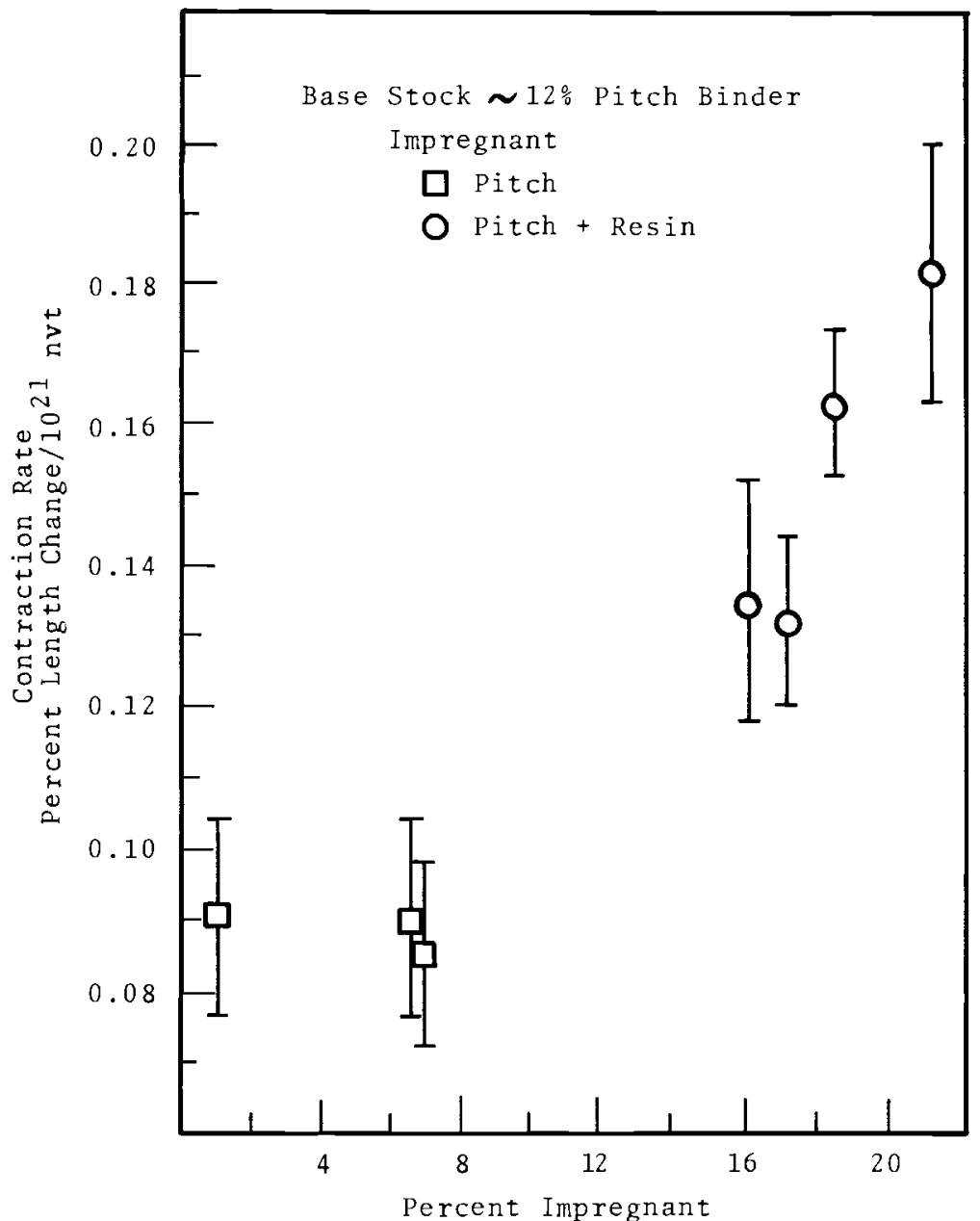

FIGURE 8. Impregnant Level Series, Radiation Induced Contraction Rate Versus Percent Impregnant (Transverse orientation)

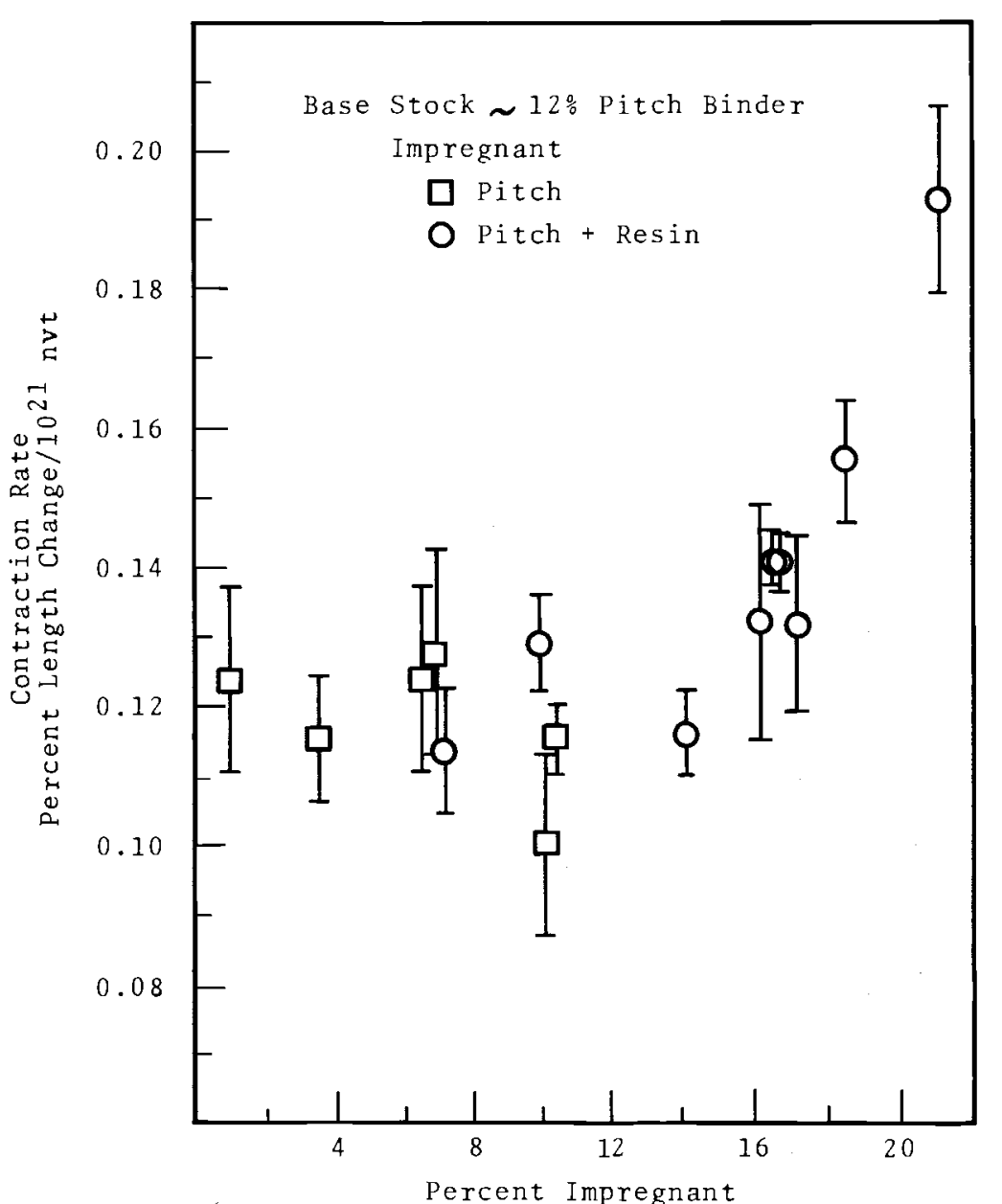

ヒั

FIGURE 9. Impregnant Level Series, Radiation Induced Contraction Rate Versus Percent Impregnant (Parallel orientation) 
One explanation of this behavior is the preferential filling of open pores until the binder becomes part of the supporting structure. Up to an impregnant level of $16 \%$ there is no effect because the impregnant is filling the open pores and shrinking away during graphitization. However, as the impregnant level approaches the open pore volume, the impregnant becomes part of the supporting structure after going through the graphitization step in processing. As a result the dimensional behavior of the bulk under neutron irradiation is determined not only by the behavior of the filler material but also by the behavior of the binder and impregnant material, as indicated by de Halas and Yoshikawa. (11) As the impregnant level is raised, it contributes more to the bulk behavior.

\section{DENSITY}

The initial property measurements for the density series are given in Table $\mathrm{V}$.

\begin{tabular}{|c|c|c|c|c|c|c|c|}
\hline \multirow[b]{3}{*}{ Material } & \multirow{3}{*}{$\begin{array}{l}\text { Densi } \\
\text { Density } \\
(\mathrm{g} / \mathrm{cc})\end{array}$} & \multirow{2}{*}{\multicolumn{2}{|c|}{$\begin{array}{l}\text { ries: Initial Pro } \\
\text { Coefficient of } \\
\text { Therma } 1 \text { Expansion } \\
\left(25-425{ }^{\circ} \mathrm{C}\right) \\
\times 106 /{ }^{\circ} \mathrm{C} \\
\end{array}$}} & \multicolumn{4}{|c|}{ Measurements } \\
\hline & & & & Crys & a11ite & imen & ons, $\AA$ \\
\hline & & $\perp$ & II & $\underline{\mathrm{L}_{\mathrm{c}}}$ & c & $\stackrel{\mathrm{L}}{\mathrm{a}}$ & a \\
\hline $\begin{array}{l}\text { Needle Coke } \\
\text { Coa1-Tar Pitch }\end{array}$ & 1.41 & 4.73 & 1.21 & 527 & 6.727 & 684 & 2.4621 \\
\hline $\begin{array}{l}\text { Need1e Coke } \\
\text { Petroleum Pitch }\end{array}$ & 1.30 & 5.05 & 1.23 & 496 & 6.736 & 673 & 2.4627 \\
\hline TSX & 1.71 & 3.52 & 0.89 & 645 & 6.727 & 685 & 2.4644 \\
\hline
\end{tabular}

The irradiation data for the density series is presented in Figure 10. As a reference, TSX graphite is also plotted. The data show that low density does not necessarily imply a high contraction rate; both low density sample sets show improved stability compared to the standard TSX. 


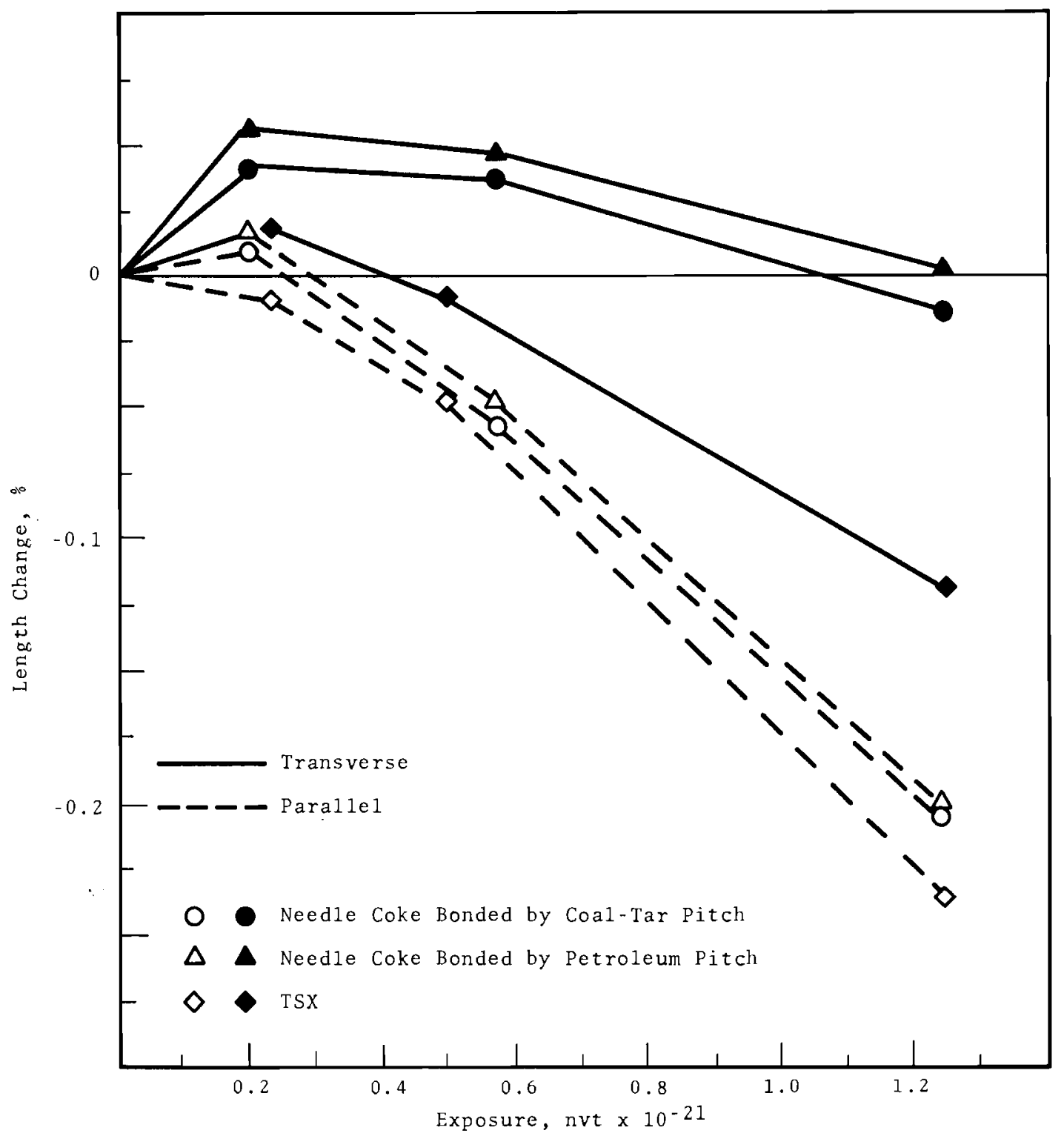

FIGURE 10. Low Density Series, Radiation Induced Length Changes

\section{LIMITATION}

It should be noted that these results are reported for relatively low exposure compared to reactor lifetime exposures. As a result, although several conclusions can be made relating the radiation-induced contraction rate of graphite to processing variables, full reactor lifetime exposures are required to determine behavior of a graphite moderator assembly. 


\section{ACKNOWJEDGEMENTS}

The author acknowledges the work of E. M. Woodruff who initiated the irradiation of several sample series reported. Special thanks go to A. J. Jervis, Jr., for many long and tedious hours of sample measurement and data tabulation.

\section{REFERENCES}

1. W. H. Zimmer. The Gamma Analytical System at Redox, RL-SEP-46. General Electric Company, Richland, Washington, September 1964.

2. W. C. Morgan. FOILS, A Program for Computing Neutron Exposures from Foil-Activation Data, HW-81367. General Electric Company, Richland, Washington, Apriz 1964.

3. W. A. Hedden, L. D. Luch, and J. A. Slyk. Experimental Carbons and Graphites for Irradiation Studies, BMI-962. Battelie Memorial Institute, Cleveland, ohio, october 1954.

4. R. W. Merek and W. C. Parker. Exploration of the Effects of Some Process Variables on the Radiation Induced Contraction of Graphite, SCC-19. Speer Carbon Company, Niagara Fazis, July 1963 .

5. W. V. Kotzensky and D. B. Fishbach. Tensize and Structural Properties of Glassy Carbon, JPL-TR-32-841. Jet Propulsion Laboratory, California Institute of Technology, Pasadena, California, 1965.

6. J. T. Meers and J. F. Doar. High Temperature Radiation Damage to Graphite, Part 1, Preparation of Graphites for Irradiation, HW-80752. General Electric Company, Ricilland, Washington, Apriz 1964.

7. J.H.W. Simmons. "The Effects of Irradiation on the Mechanical Properties of Graphite," Third Conference on Carbon. Pergamon Press, 1957 . p. 559.

8. D. P. Rizey. "The Thermal Expansion of Graphite; Part II, Theoretical," Proc. Phys. Soc., vol. 57, p. 486. London, 1945 .

9. H. H. Yoshikawa. The Effect of Radiation on Pyrolytic Graphite, HW-78645. General Electric Company, Richland, Washington, January 1964.

10. B. T. Kelzey, W. H. Martin, and P. T. Nettrey. "Dimensional Changes in Pyrolytic Graphite under Fast Neutron Irradiations," Phil. Trans. A., vol. 260, pp. 37-49, June 1966.

11. D. R. de Halas and H. H. Yoshikawa. Fifth Carbon Conference, vol. 1, p. 249. Pergamor Press, London, 1962. 


\section{$\underline{\text { DISTRIBUTION }}$}

No. of

Copies

8
AEC Library, Washington

Division of Reactor Development

J. E. Fox (2)

R. E. Pahler

J. M. Simmons

W. L. R. Rice

Division of Production

W. J. Lindsey

F. P. Self

C. W. Showalter

AEC Richland Operations Office

R. L. Plum (2)

C. R. Qualheim (2)

C. L. Robinson

R. K. Sharp

Technical Information Library

AEC Senior RDT Site Rep., Richland

P. G. Holsted

Atomic Energy Research Establishment Metallurgy Division

Harwel1

Didcot, Berkshire, England

J. H. W. Simmons (2)

W. N. Reynolds

Atomics International

K. W. Foster

Argonne National Laboratory

R. M. Adams

Atomics Power Development. Associates 1911 First Street, Detroit, Michigan

W. E. McHugh

Basic Carbon Corporation

Sanborn, New York

H. M. Killmar 
No. of

Copies

1

2

3
Brookhaven National Laboratory

D. H. Gurinsky

Centre d'Etudes Nucleaires de Saclay

Boite Postale No. 2

Gif-sur-Yvette (Seine-et-Oise), France

J. Rappeneau

Culcheth Laboratories

Reactor Materials Laboratory

UKAEA

Wigshaw Lane

Warrington, Lancashire, England

B. T. Kelly (2)

P. T. Nettley

Division of Technical Information Extension

Douglas United Nuclear, Inc.

P. C. Carlson

R. Cooperstein

D. H. Curtiss

A. Russell

Dragon Project Office

Atomic Energy Establishment Winfirth

Dorchester, Dorset, England

L. W. Graham (2)

R. A. U. Huddle

General Atomic Division

G. B. Engle (2)

R. A. Meyer

R. Turner

Great Lakes Carbon Corporation Research and Development Department P. O. Box 637, Niagara Falls, New York

L. H. Juel, Electrode Division

Lawrence Radiation Laboratories

Livermore, California

Dr. James Hadley 
No. of

Copies

1

3

2

2

20

2

2

5

1
Marquardt Corporation

D. W. Bareis

Oak Ridge Operations Office

W. J. Larkin

D. F. Cope (2)

POCO Graphite, Inc. Garland, Texas

R. K. Carlson

Pure Carbon Company

St. Marys, Pennsylvania

R. R. Paxton

Reactor Centrum Nederland

Patten, Nederland

R. Blackstone

Speer Carbon Company

Research and Development Laboratories

Packard Road \& 47 th Street, Niagara Falls, N.Y.

W. E. Parker

R. W. Marek

THTR Projektleitung

517 Julich

bei Aachen, West Germany

L. Valette

Union Carbide Corporation (ORNL-X-10)

R. Kennedy

Union Carbide Corporation (ORNL-Y-12)

B. L. Greenstreet

F. J. Witt (2)

Union Carbide Corporation, Cleveland

J. T. Meers 
No. of

Copies

1

1

1

39 $\frac{\text { Union Carbide Corporation }}{\text { Lawrenceburg, Tennessee }}$

L. D. Stoughton

Union Carbide Corporation

270 Park Avenue, New York, New Yorh

Wright Air Development Division

Wright-Patterson AFB, Ohio

Battelle-Northwest

F. W. Albaugh

D. E. Baker

J. H. Cox, Jr. (20)

G. M. Dalen

E. A. Evans

J. W. Helm

A. J. Jervis, Jr.

ii. C. Morgan

R. E. Nightingale

A. L. Pitner

G. L. Tingey

E. M. Woodruff

H. H. Yoshikawa

Technical Information Files (5)

Technical Publications (2) 